\title{
Role of Different Substrates and Organic Supplements on Growth and Yield of Different Strains of Calocybe indica
}

\author{
Veer Singh*, Dheeraj Baghel, C.S. Shukla and H.K. Singh
}

Department of Plant Pathology, College of Agriculture, I.G.K.V., Raipur (C.G.), India

*Corresponding author

\begin{tabular}{l} 
Ke y w o r d s \\
$\begin{array}{l}\text { Milky mushroom } \\
\text { (Calocybe indica), } \\
\text { Organic } \\
\text { supplement, } \\
\text { Substrate, Spawn } \\
\text { run }\end{array}$ \\
\hline Article Info \\
$\begin{array}{l}\text { Accepted: } \\
22 \text { October } 2019 \\
\text { Available Online: } \\
\text { 10 November } 2019\end{array}$ \\
\hline
\end{tabular}
Organic

run

\section{A B S T R A C T}

Fungi are worldwide cultivated for the human consumption and called as mushrooms. Among the cultivated mushroom, Calocybe indica, known as milky mushroom and grown at high temperatures and relative humidity. The present study was undertaken to find out the best suited strain, substrate and supplements to enhance the yield of $C$. indica. Five strains (CI-1, CI-2, CI-3, CI-4 and CI-5) of $C$. indica were grown on unexplored locally available differents (wheat, soybean, paddy, sesamum straw and sugarcane bagasses) substrates and 2 organic supplements i.e. rice bran (2\% $\& 5 \%)$ and wheat bran (2\% and 5\%). Among the different substrate, earlier (18.44 days) spawn run and primordial initiation (15.44 days) was obtained from wheat straw and also gave maximum (320.04 g) yield. No spawn run was observed on paddy and sesamum straw. Among, organic supplements, $2 \%$ Wheat bran required significantly less time for spawn run (21.12 days) and primordial initiation (11.24days) but higher (373.08 g) yield of $C$. indica was records in $2 \%$ rice bran.

\section{Introduction}

Milky mushroom (Caocybe indica) is a promising mushroom which was introduced to the world as edible mushrooms from India (Purkayastha, et al.,1974) and can be cultivated on lignin rich agricultural wastes, milky mushroom (Calocybe indica) is relatively new to the world of mushroom industry and first time reported from West
Bengal, India (Purakayasha, 1974). It is also known as "Dudh Chhatta/Milky Mushroom" because of its milky white appearance and large sized sporophores or as "white summer mushroom" because of its tropical nature, rich with protein, lipids, mineral, fiber, carbohydrate and is abundant with essential amino acids (Alam et al., 2008, Mall vandharri et al., 2006). Milky mushroom grew well on uncomposted substrate on wide range 
of cellulosic substrate under artificial cultivation. According to Moda et al., (2005) supplementing the substrate increase productivity, which is evaluated by biological efficiency. The most common organic nitrogen supplements are cereal bran, which are necessary for mycelia growth but interfere the productivity and biological efficiency of the mushrooms. The quantity and kind of bran varied according to the species or strain of mushroom as well as the growth stage. Rice bran is the most popular and available organic substrate additive for growing a number of edible mushrooms in Asia.

\section{Materials and Methods}

\section{Mushroom strain}

The culture of different strains of $C$. indica viz. CI-1, CI-2, CI-3, CI-4 and CI-5 were procured from All India Co-ordinate Mushroom Research Project center, IGKV, Raipur, Chhattisgarh.

\section{Preparation of mother spawn}

Mother spawn of five strains (CI-1, CI-2, CI3, CI-4 and CI-5) of $C$. indica was prepared on wheat grains, The grains were processed as per standard procedure cooled grains were mixed by $2 \%$, gypsum and calcium carbonate. These process thoroughly grains were filled in conical flask $(250 \mathrm{ml})$, plugged with nonabsorbent cotton and sterilized at 20 lbs. psi for 2 hours. After cooling, grains were inoculated with actively growing mycelium of five strains of $C$. indica, then incubated at $30^{\circ} \mathrm{C}$ till the mycelium covered the entire grain surface.

\section{Preparation of commercial spawn}

It was prepared on wheat grains in poly propylene bags $(6 " \times 11 "-150$ gauges $)$ and each bag contains $250 \mathrm{~g}$ grain. Thereafter bags were sterilized at $20 \mathrm{lbs}$. psi for 2 hours. After cooling bags were aseptically inoculated with one spoon of mother spawn and incubated at $30^{\circ} \mathrm{C}$. The inoculated bags were showing white, silky, uniform, strand mycelial growth covering all the grains was used for experimentation.

\section{Preparation of substrate}

The substrate was dipped in plain water for 4 hours thereafter water was drained off and boiled in hot water for 5-10 minutes. Then, excess water was drained off and spread over on sloppy, cemented floor till the moisture content of straw remained 65-70 per cent. Before spawning, formaldehyde was sprinkled on floor and spawn was mixed in substrate through layer method @ 10\% on dry weight basis in all experiments. The spawned substrate was filled in poly propylene bags $(18 " \times 27 "-150$ gauges $)$ and mouth of the spawned bags was tied with nylon string.

\section{Preparation of Casing materials.}

A $3 \mathrm{~cm}$ thick layer of casing soil (Soil + Vermicompost + Cocopite, 1:1:1) was applied on the upper surface of complete colonized by mycelium of $C$. indica. The casing soil prior to use was sterilized with formalin (5\%) for 48 hours. After putting casing material bags were transferred in mushroom growing room where temperature of $30-35{ }^{\circ} \mathrm{C}$ and relative humidity of $>80 \%$ was maintained.

\section{Effect of different substrates on growth and yield attributing parameters}

To know the impact of different straw substrates on spawn run, primordial initiation and yield of 5 strains of $C$. indica. was studied and 05 substrates i.e. paddy straw, wheat straw, soybean straw, seas mum straw and sugarcane bagasses were taken. Each substrate was soaked in plain water for $4 \mathrm{hrs}$. separately 
then pasturized by hot water. After pasteurization hot water was decanted and spreaded on sloppy concrete floor and dried in shed to maintain the appropriate moisture content (60-65\%). Then substrates were spawned by respective strains of $C$. indica and filled in polypropylene bag by layer method @ $10 \%$ on dry weight basis of substrate. Each bag contained $500.0 \mathrm{~g}$ dry substrate and replicated 05 times. Spawned bags were tied with nylon string and perforated by making holes 8-10 in each bag with the help of pokar for gaseous exchange. The bags were kept for spawn run where temperature $30 \pm 10^{\circ} \mathrm{C}$ and > $80 \%$ relative humidity was maintained. After spawn run, mouth of bags was opened and casing was done. The observation was recorded for spawn run, initiation of primordial and yield of $C$. indica per bag.

\section{Effect of supplementation on growth and yield attributing parameters}

Two organic supplements i.e. rice bran and wheat bran were evaluated @ 2 and 5\% on dry weight basis to see their effect on growth and yield of $C$. indica, The experiment was laid out in the month of May- June during 2017. The above supplements were thoroughly mixed in wheat straw (500g dry straw/bag), just before spawning. In control, no supplement was added in substrate. Observations were recorded for spawn run, time required for pin head formation, fresh yield and BE. Five replications were maintained for each treatment and substrates.

\section{Experimental design}

All the experiments were conducted using factorial - CRD and critical difference (C.D.) was calculated at 5\% levels. The data were analyzed according to standard methods using the OPISTAT program. Biological Efficiency was calculated as per formula given by Chang et al., (1981).
Biological Efficiency (\%)

$=$ Fresh weight of mushroom/ Dry weight of substrate $\times 100$

\section{Results and Discussion}

To find out the suitable substrate for growth and yield of $C$. indica

The data are presented table 1 clearly indicate that among the evaluated substrate wheat straw took significantly less (18.44 days) period as compare to other substrate for spawn run, however, significantly more (23.20days) time sugarcane bagasses and soybean straw (21.96days). No spawn run was noticed in paddy and sesamum straw. Significantly earliest (15.4 days) premordial initiation was noticed in wheat straw and it significantly delayed in soybean straw (19.5days) and sugarcane bagasses (19.96days) which were at par with each other. Similarly, wheat straw gave significantly more (320.04 gm) yield as compare to soybean straw (260.4gram) and sugarcane bagasses (221.89 gm).

Among the evaluated different strains of $C$. indica, CI-1 gave earlier spawn run (17.73days), pinhead initiation (15.60 days) and also gave more yield as compare to other strains of Calocybe indica. Whereas CI-2 took considerably more period for spawn run and pin head initiation (24.8 and 21.26 days respectively) with minimum (187.2 gm) yield.

Interaction of substrates $\mathrm{x}$ strains did also exhibit significant difference in spawn run, primordial initiation and yield of different strains of $C$. indica, different strains differ statistically with each other. Strain CI-5 gave significantly less period (15.60days and 12.40 days) for spawn run and primordial initiation respectively on wheat straw. However CI-1 gave highest $(369.40 \mathrm{~g})$ yield on wheat straw. Arora et al., (2004), also have been obtained maximum yield of $C$. indica on wheat straw (Fig. 1 and 2; Table 2). 


\section{Int.J.Curr.Microbiol.App.Sci (2019) 8(11): 2263-2269}

Table.1 Evaluation of different substrates on growth and yield of different strains of $C$. indica

\begin{tabular}{|c|c|c|c|c|c|c|c|c|c|c|c|c|c|c|c|c|c|c|c|}
\hline \multirow[t]{2}{*}{ Substrates } & \multicolumn{6}{|c|}{$\begin{array}{l}\text { Spawn run } \\
\text { (Days) }\end{array}$} & \multicolumn{6}{|c|}{$\begin{array}{l}\text { Primordial initiation } \\
\text { (Days) }\end{array}$} & \multicolumn{6}{|c|}{ Yield (g.)* } & \multirow[t]{2}{*}{$\begin{array}{l}\text { B.E } \\
(\%)\end{array}$} \\
\hline & CI-1 & CI-2 & CI-3 & CI-4 & CI-5 & Average & CI-1 & CI-2 & CI-3 & CI-4 & CI-5 & Average & CI-1 & CI-2 & CI-3 & CI-4 & CI-5 & Average & \\
\hline $\begin{array}{l}\text { Wheat } \\
\text { straw }\end{array}$ & 17.40 & 21.80 & 18.00 & 19.40 & 15.60 & 18.44 & 14.40 & 18.60 & 15.60 & 16.20 & 12.40 & 15.44 & 369.40 & 232.00 & 335.60 & 301.20 & 362.00 & 320.04 & 64.00 \\
\hline $\begin{array}{l}\text { Soybean } \\
\text { straw }\end{array}$ & 20.40 & 25.60 & 22.20 & 23.80 & 17.80 & 21.96 & 18.60 & 22.20 & 19.80 & 20.60 & 16.60 & 19.56 & 294.60 & 182.20 & 273.20 & 235.40 & 317.80 & 260.64 & 52.12 \\
\hline $\begin{array}{r}\text { Sugarcane } \\
\text { bagasses }\end{array}$ & 21.60 & 27.00 & 22.80 & 24.80 & 19.80 & 23.20 & 18.20 & 23.00 & 19.80 & 21.00 & 17.80 & 19.96 & 248.80 & 147.40 & 230.60 & 191.60 & 290.60 & 221.80 & 44.36 \\
\hline $\begin{array}{l}\text { Paddy } \\
\text { straw }\end{array}$ & - & - & - & - & - & - & - & - & - & - & - & - & - & - & - & & - & - & - \\
\hline $\begin{array}{c}\text { Sesamum } \\
\text { straw }\end{array}$ & - & - & - & - & - & - & - & - & - & - & - & - & - & - & - & & - & - & - \\
\hline \multirow[t]{2}{*}{ Average } & 19.80 & 24.80 & 21.00 & 22.66 & 17.73 & & 17.06 & 21.26 & 18.40 & 19.26 & 15.60 & & 313.26 & 187.20 & 279.80 & 242.73 & 323.46 & & \\
\hline & \multicolumn{3}{|c|}{ SEm \pm} & \multicolumn{3}{|c|}{$\mathrm{CD}(5 \%)$} & \multicolumn{3}{|c|}{ SEm \pm} & \multicolumn{3}{|c|}{$\mathrm{CD}(5 \%)$} & \multicolumn{3}{|c|}{ SEm \pm} & \multicolumn{3}{|c|}{$\mathrm{CD}(5 \%)$} & \\
\hline Strains & \multicolumn{3}{|c|}{0.16} & \multicolumn{3}{|c|}{0.47} & \multicolumn{3}{|c|}{0.25} & \multicolumn{3}{|c|}{0.72} & \multicolumn{3}{|c|}{4.66} & \multicolumn{3}{|c|}{13.21} & \\
\hline Substrates & \multicolumn{3}{|c|}{0.21} & \multicolumn{3}{|c|}{0.61} & \multicolumn{3}{|c|}{0.33} & \multicolumn{3}{|c|}{0.94} & \multicolumn{3}{|c|}{6.01} & \multicolumn{3}{|c|}{17.06} & \\
\hline $\begin{array}{l}\text { Strains } \times \\
\text { Substrates }\end{array}$ & \multicolumn{3}{|c|}{0.37} & \multicolumn{3}{|c|}{ N/A } & \multicolumn{3}{|c|}{0.57} & \multicolumn{3}{|c|}{ N/A } & \multicolumn{3}{|c|}{10.42} & \multicolumn{3}{|c|}{ N/A } & \\
\hline
\end{tabular}




\section{Int.J.Curr.Microbiol.App.Sci (2019) 8(11): 2263-2269}

Table.2 Effect of organic supplement on growth and yield of different strain of $C$. indica

\begin{tabular}{|c|c|c|c|c|c|c|c|c|c|c|c|c|c|c|c|c|c|c|c|}
\hline \multirow[t]{2}{*}{ Treatment } & \multicolumn{6}{|c|}{$\begin{array}{l}\text { Spawn run } \\
\text { (Days) }\end{array}$} & \multicolumn{6}{|c|}{$\begin{array}{c}\text { Primordial initiation } \\
\text { (Days) }\end{array}$} & \multicolumn{6}{|c|}{ Yield (g.)* } & \multirow[t]{2}{*}{$\begin{array}{l}\text { B.E. } \\
(\%)\end{array}$} \\
\hline & CI-1 & CI-2 & CI-3 & CI-4 & CI-5 & Average & CI-1 & CI-2 & CI-3 & $\mathrm{CI}-4$ & CI-5 & Average & CI-1 & $\mathrm{CI}-2$ & CI-3 & $\mathrm{CI}-4$ & CI-5 & Average & \\
\hline Rice- $2 \%$ & 22.00 & 27.80 & 23.00 & 25.60 & 20.80 & 23.84 & 11.00 & 16.00 & 12.60 & 14.60 & 10.40 & 12.92 & 407.40 & 263.60 & 383.80 & 358.40 & 452.20 & 373.08 & 74.61 \\
\hline Wheat-2\% & 19.00 & 24.00 & 22.20 & 23.20 & 17.20 & 21.12 & 9.20 & 14.00 & 11.60 & 13.00 & 8.40 & 11.24 & 392.00 & 246.40 & 364.60 & 334.40 & 431.80 & 353.84 & 70.76 \\
\hline Rice-5\% & - & - & - & - & - & - & - & - & - & - & - & - & - & - & - & - & - & - & - \\
\hline Wheat-5\% & - & - & - & - & & -- & & - & - & - & - & - & - & - & - & - & - & - & - \\
\hline Control & 21.60 & 27.00 & 24.40 & 27.20 & 20.20 & 24.08 & 14.60 & 18.00 & 15.80 & 16.20 & 13.00 & 15.52 & 356.20 & 235.20 & 328.40 & 291.60 & 380.80 & 318.44 & 63.68 \\
\hline Average & 20.86 & 26.26 & 23.20 & 25.33 & 19.40 & & 11.60 & 16.00 & 13.33 & 14.60 & 10.60 & & 385.20 & 248.40 & 358.93 & 328.13 & 421.60 & & \\
\hline & & SEm \pm & & & $\mathrm{CD}\left(5^{\circ}\right.$ & & & SEm \pm & & & $\mathrm{CD}\left(5^{\circ}\right.$ & & & SEm \pm & & & CD $(5 \%$ & & \\
\hline Strains & & 0.43 & & & 1.24 & & & 0.55 & & & 1.55 & & & 5.27 & & & 14.94 & & \\
\hline Bran & & 0.56 & & & 1.60 & & & 0.71 & & & 2.01 & & & 6.80 & & & 19.29 & & \\
\hline $\begin{array}{c}\text { Strains } \times \\
\text { Bran }\end{array}$ & & 0.97 & & & N/A & & & 1.23 & & & N/A & & & 11.78 & & & N/A & & \\
\hline
\end{tabular}


Fig.1 Effect of organic supplements on spawn run, primordial initiation, and yield of different strain of $C$. indica
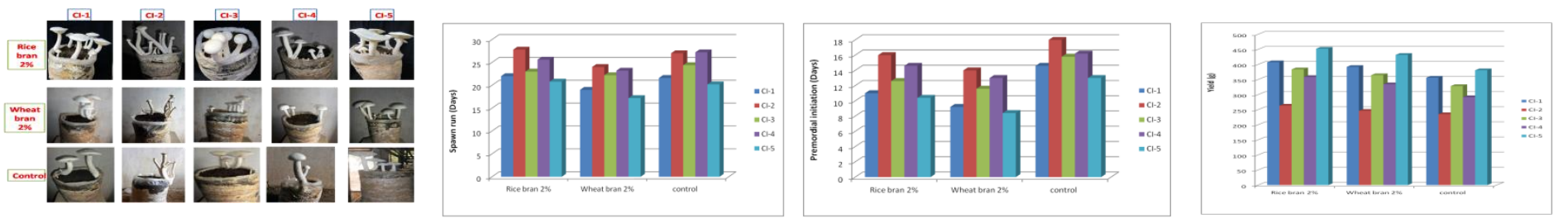

Fig.2 Effect of different substrate on spawn run, primordial initiation, and yield of $C$. indica strains
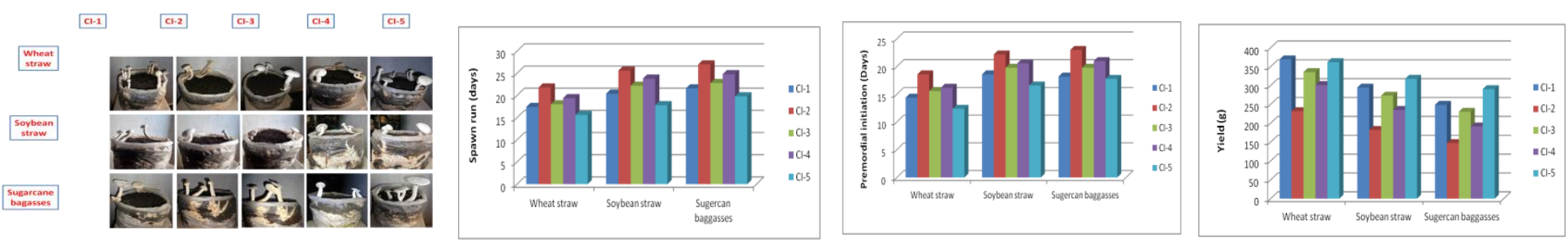

Wheat straw gave quickest colonization of substrate, earlier primordial initiation with more yield of $C$. indica (Tandon and Sharma, 2006; Dayaram, 2009; Prasuna 2002; Kumar et al., 2014).

\section{Effect of organic supplement on growth and yield of different strain of $C$. indica}

The substrate supplemented with $2 \%$ wheat bran required significantly less time (21.12 days) for spawn run as compared to control (24.08 days). There was no significant difference noticed in substrate supplemented by $2 \%$ rice bran and control. Significantly earlier primordial initiation was observed in $2 \%$ wheat bran (11.24 days), $2 \%$ rice bran (12.92 days) as compared to control (15.5 days).

Significantly the fresh yield of $C$. indica was more recorded in $2 \%$ rice bran $(373.08 \mathrm{~g})$ and $2 \%$ wheat bran $(353.84 \mathrm{gm})$. On an average, the spawn run, primordial initiation and yield in different strains of $C$. indica significantly differ with each other. Strain CI-5 took significantly lesser period for mycelial on substrate and initiation of pin head (19.40 and 10.60 days respectively), also gave significantly higher yield $(421.60 \mathrm{gm})$ with $74.61 \%$ B.E.

However, strain CI-1 and CI-4 required more period for complete mycelial calonization of substrate primordial initiation and yield less as compare to other strains. The substrate supplement with $5 \%$ rice bran and wheat did not show spawn run. Interaction of supplement $\mathrm{x}$ strains did not exhibit significant difference in spawn run, primordial initiation and yield of different strains of $C$. indica. Enhancement in fresh yield of $C$. indica with the supplementation $2 \%$ Rice bran and wheat bran has been observed by Shukla (2003).

This study concluded, different agro wastes and brans were used as substrate and organic supplementation for enhance the yield of $C$. indica where Wheat straw was the most suitable substrate for cultivation of $C$. indica. Supplementation with $2 \%$ rice bran was most suitable for enhancing the yield of $C$. indica 


\section{References}

Alam, N., Amin, R., Khan. A., Arag, Shim M.J, Lee M.W, Lee, T. S., 2008. Nutritional analysis of cultivated mushrooms in Bangladesh. Pleutrotus ostreatus, Pleurotus sajor-caju, Pleurotus florida and calcybe indica. Microbiology, 36(2): 28-32.

Arora, R.K., Mishra, K.K., Verma, R.C. and Singh, R.P., (2004) Evaluation of substrate for yield of Calocybe indica, In: International Conference Mushroom Biology and Biotechnology, pp. 137.

Dayaram, (2009)Cultivation of milky white mushroom in Bihar, India, J Mycol Pl Pathol, 39: 283-285.

Kumar, R., Singh G. and Mishra P. 2015. Influence of different substrates and Environmental factors on yield of two strains of Calocybe indica. J. Mycopathol. Res. Vol. 53(1): 75-82.

Mallavadhani, U.V., Sudhakar, A.V., Satyanarayana, K.V.S., Mahapatra, A. and $\mathrm{Li}, \mathrm{W}$. 2006. Chemical and analytical screening of some edible mushrooms. Food Chemistry, 95(1): 58-64.

Moda EM, Horii J, Spoto MH. Edible mushroom Pleurotus sajor-caju production on washed and supplemented sugarcane bagasse. Sci Agric 2005; 62: 127-32.

Pandey, M. and Tewari, R.P. 1993. Milky mushroom grown on paddy straw. The Hindu.Dec, 93, p.24.

Peng JT, Lee CM, Tsai YF. Effect of rice bran on the production of different king oyster mushroom strains during bottle cultivation. J Agric Res China 2000; 49: 60-7.

Prasuna, K., 2002. Studies on nutritional and environmental factor effecting growth and yield of Calocybe indica. Ph. D. Thesis submitted to Osmania University, Hydrabad, Pp. 176.

Purkayastha, R.P. and Chandra, A. 1974. New species of edible mushroom from India. Transactions of the British Mycological Society, 62 (2): 415-418.

Purkayastha, R.P. 1984. Cultivation of Calocybe indica $(\mathrm{P} \& \mathrm{C})$. Indian $\mathrm{J}$ Mushrooms, pp.10-7.

Shukla, C.S. 2003. Role of Agronomical and Biochemical Parameters on Growth and Yield of Calocybe indica ( $\mathrm{P} \& \mathrm{C})$. PH. D. Thesis, COA, IGKV, Raipur (CG). Pp. 148.

Tandon, G. and Sharma, V.P. 2006. Yield performance of Calocybe indica on various substrates and supplements, Mushroom Res, 15: 33-35.

\section{How to cite this article:}

Veer Singh, Dheeraj Baghel, C.S. Shukla and Singh, H.K. 2019. Role of Different Substrates and Organic Supplements on Growth and Yield of Different Strains of Calocybe indica. Int.J.Curr.Microbiol.App.Sci. 8(11): 2263-2269. doi: https://doi.org/10.20546/ijcmas.2019.811.263 